\title{
Enrichment experiments and infaunal population cycles on a Southern California sand plain: response of the leptostracan Nebalia daytoni and other infauna
}

\author{
Eric W. Vetter* \\ Scripps Institution of Oceanography, UCSD 0201, 9500 Gilman Drive, La Jolla, California 92093-0201, USA
}

\begin{abstract}
Field studies on the effects of pulsed enrichments were carried out on macrofaunal invertebrates inhabiting the sandy bottom at a depth of about $20 \mathrm{~m}$ off the coast of Southern California, USA. Contrary to expectation, no members of the community studied responded positively to patches artificially enriched with organic material (kelp, fertilizer, or parcels of fish flesh). Although other members of the leptostracan genus Nebalia respond favorably to carrion and heavily enriched conditions, $N$. daytoni, one of the most common animals at the study site, showed no response to the enrichments. All other members of the infaunal community declined in abundance in enriched plots, although the opportunistic polychaete Capitella sp. recruited heavily into them. In the unenriched habitat, seasonal cycles of abundance were evident for most groups of macrofaunal invertebrates, but were especially strong for amphipods and $N$. daytoni.
\end{abstract}

KEY WORDS: Nebalia Capitella. Organic enrichment Seasonal cycles

\section{INTRODUCTION}

Organic enrichment has long been seen as a crucial structuring agent for the soft sediment benthos, as disturbances (Tarazona et al. 1988, Ritz et al. 1989), a source of heterogeneity (Snelgrove et al. 1992, Grassle \& Grassle 1994), or as periodic events necessary for normal community function (Smith 1986, Tsutsumi 1990) depending on the scale, intensity, and location of the enrichment. The immediate source of enrichment may be anthropogenic or natural. Where organic enrichment is massive (e.g. at some sewage outfalls) one commonly observes decreased mean body size, biomass and diversity; restriction of macrofauna to nearsurface sediments; and changes in dominance (Pearson \& Rosenberg 1978, Swartz et al. 1986, Weston 1990). However, where the volume of effluent or physical conditions result in only moderate enrichment around outfalls, less predictable effects including in-

•E-mail: ewvetter@ucsd.edu creased diversity and biomass (Dauer \& Conner 1980) or instability of benthic communities (Zmarzly et al. 1994) are possible. Exceptionally, where organic enrichment from outfalls is great, it may result in increases in biomass, diversity and abundance if it occurs in regions which are already disturbed and are naturally high in organic matter (Ansari et al 1986) Substrate enrichment is also an important part of deepsea biology, either as a local, massive food fall (e.g. a whale carcass) or as a much less intense, but very widespread rain of detritus (Dayton \& Hessler 1972, Thiel 1978, Smith 1985, Levin \& Thomas 1989, Smith et al. 1989, Priede et al. 1991, Snelgrove et al. 1992, Bennett et al. 1994, Levin et al. 1994, Rice \& Lambshead 1994). Enrichment has also been studied in shallow protected waters, especially in mud flats and estuaries. Although such environments are typically high in organic matter, many studies have shown that further enrichment is important for the persistence of some species (Thrush 1986. Tsutsumi 1990, Sardá et al. 1992) and enhances the reproduction of others (Levin 1986, Bridges et al. 1994, Levin et al. 1994). 
Most research on benthic enrichment has been conducted in regions where hydrodynamic conditions are likely to allow organic matter to accumulate and decompose in place. In one of few studies on smallscale enrichments to sandy sediments exposed to strong wave-generated surge, VanBlaricom (1982) found that pits created by foraging rays accumulated organic matter which attracted some members of the infaunal community and repelled others. The leptostracan crustacean Nebalia daytoni, the sixth most abundant animal during VanBlaricom's study, was apparently unaffected by the small-scale, low-intensity enrichments provided by detrital material in the ray pits. This is surprising considering that essentially all natural history information on the genus Nebalia refers to these animals as living in habitats rich in organic matter (Menzies \& Mohr 1952, Citarella 1965, Ricketts et al. 1985, Kazmi \& Tirmizi 1989, Rainer \& Unsworth 1991, Vetter 1994) or as scavengers and/or carrion feeders (Nishimura \& Hamabe 1964, Wägele 1983. Snelgrove 1993). Furthermore the genus is generally considered to specialize in low oxygen environments (Schrall 1980, Brusca \& Brusca 19g0).

The presence of large numbers of Nebalia daytoni in the sediments studied by VanBlaricom (1982) suggests either that enrichment was not limited to ray pits, or that important aspects of the natural history of this leptostracan deviate strongly from all other known members of the genus. The present study examined the community response to small-scale, high-intensity pulses of enrichment on the same sand plain investigated by VanBlaricom (1982). The seemingly incongruous use of this habitat by a leptostracan suggested that this community may be, to some degree, adapted to such disturbances. Three types of particulate enriching material were used. Kelp was the initial choice for enriching media, sodium alginate was also used to control for the possibility of unpalatable or repellent substances potentially present in kelp, and fertilizer served as a high nitrogen enrichment. Fish carcasses were used as a fourth enrichment. It was predicted that Nebalia daytoni, and perhaps some other species attracted to ray pits (the amphipods Acuminodeutopus heteruropus and Synchelidium shoemakeri and the tanaid Leptochelia dubia), would increase in density in enriched plots (VanBlaricom 1982).

\section{MATERIALS AND METHODS}

Field work was conducted using SCUBA from depths of 19 to $21 \mathrm{~m}, 0.7 \mathrm{~km}$ off the coast of San Diego (California, USA, $32^{\circ} 52^{\prime} \mathrm{N}, 117^{\circ} 15.5^{\prime} \mathrm{W}$ ) from June 1991 to September 1994 . The study area is exposed to oceanic swell and is subject to strong storm-generated surge during winter and early spring. Bottom water temperature ranged from 6 to $22^{\circ} \mathrm{C}$.

A standard protocol was followed when taking all cores. Sediments were cored with 9 clear butyrate tubes $(7.6 \mathrm{~cm}$ diameter) pushed $20 \mathrm{~cm}$ into the sediment. Sampling was haphazard, with cores taken in 3 groups of 3 cores each. Cores within each group were all taken within $1 \mathrm{~m}$ of each other, and groups of cores were separated by 4 to $8 \mathrm{~m}$. Sediments were livesieved with a $500 \mu \mathrm{m}$ mesh screen within $2 \mathrm{~h}$ of collection. Samples were fixed in $4 \%$ formalin in sea water and stained with rose Bengal for $48 \mathrm{~h}$, after which they were transferred to $70 \%$ ethanol and sorted under a dissecting microscope. On 7 dates, a single core ( $7.6 \mathrm{~cm}$ diameter, $50 \mathrm{~cm}$ into the sediment) was taken to estimate the vertical distribution of the sand plain infauna. Immediately after the core was taken, it was returned to the boat, sectioned into $5 \mathrm{~cm}$ layers and fixed for later sieving and sorting.

Habitat manipulations. Areas of bottom were isolated by enclosing them within cylindrical corrals (diameter $70 \mathrm{~cm}$, height $30 \mathrm{~cm}$ ) constructed of $1 \mathrm{~cm}$ plastic mesh (vexar ${ }^{\otimes}$ ) tied onto a steel frame, which was anchored with 4 evenly spaced rods driven $60 \mathrm{~cm}$ into the sand. Nine corrals were laid out in a $3 \times 3$ grid with a $5 \mathrm{~m}$ separation. In the first enrichment experiment, treatments consisted of enrichment, habitat addition and control corrals. Kelp mud, a product which is created when the kelp Macrocystis pyrifera is processed to extract sodium alginate, was used as the enriching medium. Kelp mud consists of roughly equal proportions of ash (perlite) and kelp (minus most of the sodium alginate), and was chosen for its fine grain size (less than the local sand), and because its organic base (kelp) is a locally available food resource. At the start of the experiment $2500 \mathrm{~g}$ of kelp mud were worked into the sediment of the 3 enrichment corrals by hand to a depth of $10 \mathrm{~cm}$.

The habitat-addition treatment was composed of several hundred $30 \mathrm{~cm}$ long ribbons of nylon fabric anchored in the corrals, designed to simulate surfgrass, while providing no additional organic matter. The remaining (3) corrals served as (cage) controls. The sand in all corrals was turned over to a depth of approximately $10 \mathrm{~cm}$ to control for the disturbance caused by mixing the kelp mud into the enrichment corrals.

For sampling, three $7.6 \mathrm{~cm}$ cores were bored in each corral and 9 control cores were bored 5 to $15 \mathrm{~m}$ away from the cages (as described above). Data from the 3 cores from each corral were averaged to give 1 value per corral. Coring was infrequent to reduce the effect of this disturbance on the animals within the corrals. Corrals were sampled 48 and $95 \mathrm{~d}$ after the treatments were introduced (28 June 1991). 
Two additional sediment enriching media were used to control for the possibility of unpalatable or otherwise repellent substances potentially present in kelp. The second enrichment experiment was comprised of 2 control corrals, 2 corrals enriched with $500 \mathrm{~g}$ of kelp mud, and 2 corrals enriched with $2500 \mathrm{~g}$ of sodium alginate (derived from kelp). Sodium alginate was chosen because it is a kelp product, but contains no tannins or phenolic compounds which are present at various concentrations in kelps, and are unpalatable to some animals (Hay \& Fenical 1988 and references therein). Corrals were sampied 18, 25, 32, and $46 \mathrm{~d}$ after the treatments were introduced (13 September 1991). With this higher frequency sampling protocol, there was a risk that sampling disturbance could affect later samples. However, this was necessary to evaluate the effects of the enrichment at a finer time scale.

The last enrichment experiment used nine $1 \mathrm{~m}^{2}$ plots without corrals, the corners of which were marked with steel rods. Three plots served as undisturbed controls; in 3 others $1800 \mathrm{~g}$ of the turf fertilizer milorganite ${ }^{\otimes}\left(6 \% \mathrm{~N}, 2 \% \mathrm{P}_{2} \mathrm{O}_{5}\right.$; activated sewage sludge) were worked into the sand; and 3 adjacent control plots were similarly disturbed without enrichment. This material differed from the other two by contributing relatively more nitrogen than carbon. These 9 plots were sampled $4,13,20,28$, and $48 \mathrm{~d}$ after the start of the experiment (20 September 1991).

Sediments from enriched plots were analyzed for organic carbon and nitrogen content 18 and $36 \mathrm{~d}$ after the enriching material was added. Control samples from unmanipulated sediments were also taken. Sediments were dried for $2 \mathrm{~d}$ at $50^{\circ} \mathrm{C}$, homagenized by grinding, and acidified with $\mathrm{HCl}$ to remove carbonates before being analyzed for carbon and nitrogen on a Perkin-Elmer 2400 CHN elemental analyzer. Statistical significance of treatment effects independent of time were evaluated with a repeated measures analysis of variance (ANOVA) using the Macintosh statistical package SYSTAT ${ }^{\circledR}$ (version 5.2).

Response to carrion. Three parcels of carrion (kelp bass Paralabrax clathratus) were staked out $3 \mathrm{~m}$ apart at a depth of $20 \mathrm{~m}$. The fish were placed in unrolled tuffy ${ }^{(1)}$ scrubbers, which provided a tube of interwoven plastic mesh (1 $\mathrm{mm}$ wide plastic ribbons). Each end of the tube was tied to a steel rod which was hammered into the sand. The tubes allowed easy access to the invertebrate macrofauna but interfered with feeding by fish, and to a lesser degree, asteroids and crabs. The experiment was sampled 24 and $72 \mathrm{~h}$ following deployment of the bait. Three $7.6 \mathrm{~cm}$ cores were taken directly adjacent to each of the carrion tubes (partially under îie fishj dnd $\hat{9}$ control cores were taken at least $3 \mathrm{~m}$ away from the bait. Statistical significance was tested using a nested ANOVA (SYSTAT ${ }^{\oplus}$, as above).
Sediment grain size distribution was measured for sand collected at 18 and $21 \mathrm{~m}$ depth in March 1995. Three cores were collected from each depth, the sediments were dried for $72 \mathrm{~h}$ at $60^{\circ} \mathrm{C}$, and shaken for 20 min each through an array of 12 geological sieves using a Ro-tap machine.

\section{RESULTS}

Habitat manipulations were carried out to test whether Nebalia daytoni and other members of the infaunal assemblage would be attracted to organically enriched sediments or regions with increased structural complexity which could provide increased living space and/or protection from predation. The first experiment using corrals containing increased organic matter (particulate Macrocystis pyrifera), or imitation surfgrass resulted in significant treatment effects for all taxa (Table 1). N. daytoni was depressed or absent in all corrals relative to controls (Fig. 1A), while amphipods were depressed in enrichment corrals (Fig. 1B). In contrast, polychaetes underwent a dramatic but temporary increase in enrichment corrals (Fig. 1C) due exclusively to Capitella sp. Of several thousand polychaetes in these cores, only 23 belonged to species other than Capitella sp. Most of the non-capitellids were spionids. The most abundant amphipods in control cores were Rhepoxynius abronius, Acuminodeutopus heteruropus, Amphideutopus oculatus, and Ampelisca compressa. $R$ abronius was never present in the enrichment plots (all experiments); all others were occasionally present at reduced density.

In the second set of habitat manipulations, the quantity of kelp mud was reduced and alginate was used as an alternative enrichment; there were no fake surfgrass corrals. Here, there were significant treatment effects only for the amphipods and polychaetes (Table 2). Nebalia daytoni was unaffected by the cages or

Table 1. Corral Expt 1 Summary of repeated measures ANOVA results. Treatments are control, corral control, fake seagrass, and enrichment (kelp mud)

\begin{tabular}{|lrccc|}
\hline Source of variation & df & MS & $F$ & $p$ \\
\hline $\begin{array}{l}\text { Nebalia daytoni: } \\
\text { Treatment }\end{array}$ & 3 & $1.51 \times 10^{1}$ & 7.54 & 0.0031 \\
Error & 14 & 2.00 & & \\
Amphipods: & & & & \\
$\quad \begin{array}{l}\text { Treatment } \\
\text { Error }\end{array}$ & 3 & $5.92 \times 10^{2}$ & 9.06 & 0.0014 \\
Fuiychaties: & 14 & $6.54 \times 10^{1}$ & & \\
$\quad$ Treatment & 3 & $1.87 \times 10^{4}$ & 165.68 & $<0.0001$ \\
Error & 14 & $1.12 \times 10^{2}$ & & \\
\hline
\end{tabular}




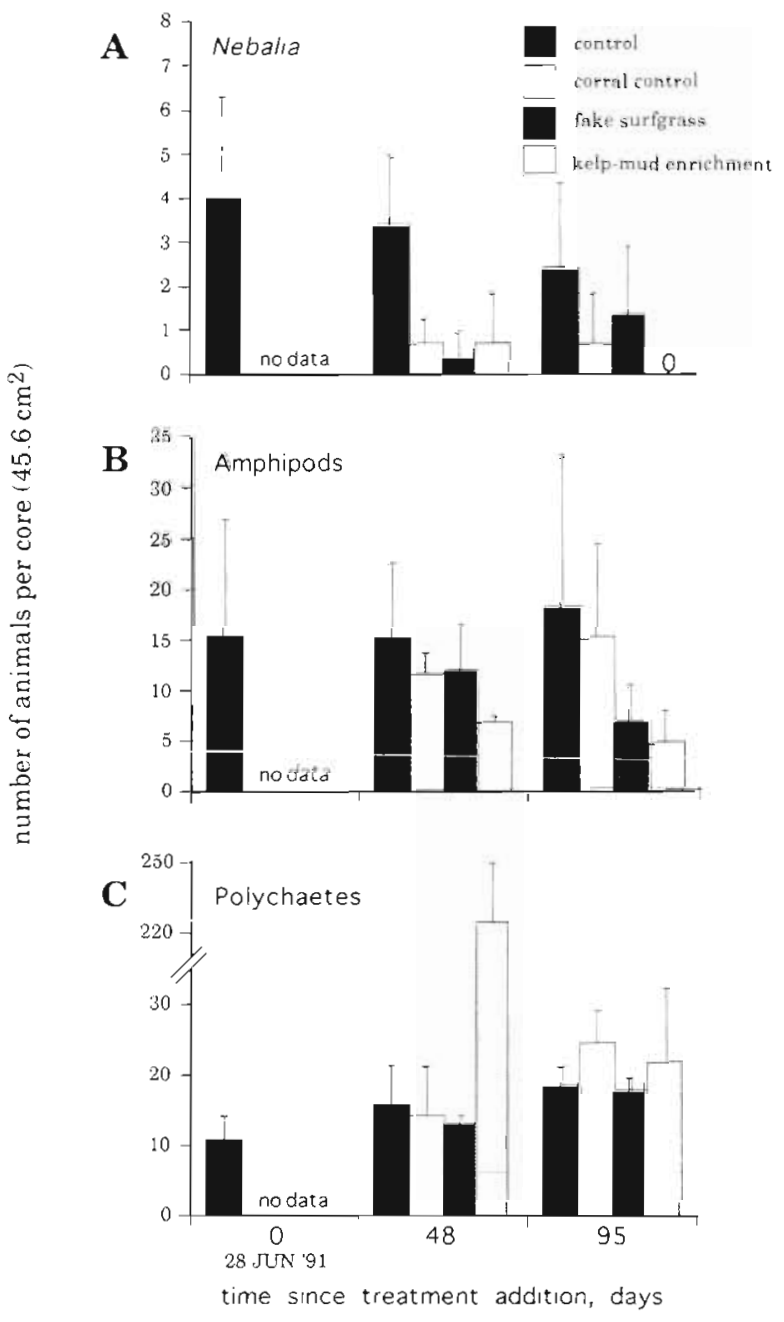

Fig. 1. Corral Expt 1. Numbers of Nebalia daytoni, amphipods, and polychaetes in unmanipulated sediments and within control corrals, and corrals enriched with kelp mud or provided with fake seagrass. Note change in scale in (C): over $99 \%$ of polychaetes in the kelp mud enrichment on Day 48 were Capitella sp. Only unmanipulated sediments were sampled on the start date (28 June 1991). Error bars are 1 SD

Table 2. Corral Expt 2. Summary of repeated measures ANOVA. Treatments are control, corral control, alginate enrichment, and kelp mud enrichment

\begin{tabular}{lcrcc}
\hline Source of variation & df & MS & $F$ & $\mathrm{p}$ \\
\hline $\begin{array}{l}\text { Nebalia daytoni: } \\
\quad \text { Treatment }\end{array}$ & 3 & 12.26 & 2.31 & 0.1530 \\
$\quad$ Error & 8 & 5.31 & & \\
$\quad$ Amphipods: & & & & \\
$\quad$ Treatment & 3 & $2.20 \times 10^{3}$ & 13.82 & 0.0015 \\
$\quad$ Error & 8 & $1.59 \times 10^{2}$ & & \\
Polychaetes: & & & & \\
$\quad$ Treatment & 3 & $1.18 \times 10^{5}$ & $153.76<0.0001$ \\
$\quad$ Error & 8 & $7.70 \times 10^{2}$ & & \\
\hline
\end{tabular}

treatments (Fig 2A); however, the amphipods' numbers were reduced by both cage and enrichment effects (Fig. 2B). The polychaetes (specifically, Capitella sp.) greatly increased in density in response to the alginate enrichment (Fig, 2C). Capitella sp. brood tubes were present in the alginate enrichments on Days 17, 24 and 38. Reproductive maturity of Capitella sp. is easily observed by the presence of eggs which line the walls of the animals' brood tubes. The animals that recruited here deposited on the order of 1000 eggs

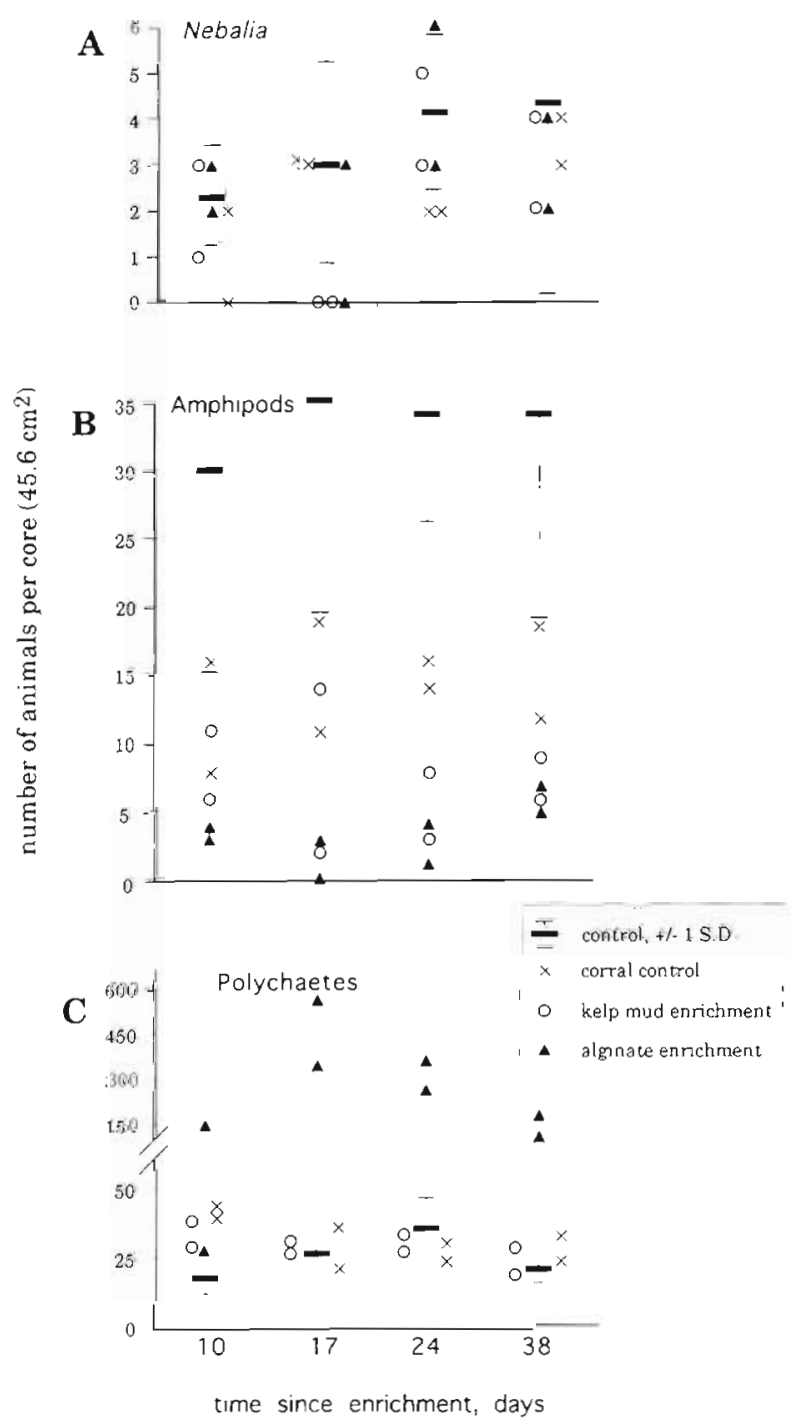

Fig. 2. Corral Expt 2. Numbers of Nebalia daytoni, amphipods, and polychaetes in unmanipulated sediments and within control corrals and corrals enriched with kelp mud or. alginate. Note change in scale in (C): Capitella sp. amounted to over $95 \%$ of polychaetes in all cores from the alginate enrichment except on Day 10, when they made up 0 and $91 \%$ of all polychaetes. There were only 2 corrals per treatment so data from each corral are provided. The mean of 9 cores is provided for the non-corral control (unmanipulated sediments). Error bars are 1 SD 
with a diameter of about $80 \mu \mathrm{m}$, suggesting that this species produces planktotrophic larvae (Grassle \& Grassle 1976, Pearson \& Pearson 1991). Reducing the kelp mud enrichment to $20 \%$ of that used in the first experiment eliminated or at least greatly reduced the effects of that manipulation relative to the previous experiment for polychaetes and the leptostracan. Amphipod density was strongly reduced by the alginate enrichment, and less so by the kelp mud enrichment (Fig. 2B).

The final enrichment experiment using fertilizer (milorganite) on un-corralled plots had similar results (Table 3). There were no significant treatment effects for Nebalia daytoni, while the amphipods were depressed and a dense population of Capitella sp. developed in the enriched plots (Fig. 3). The recruitment and growth of the Capitella sp. was extremely rapid in the enriched plots; a large number of the worms were found with brooding eggs on the first post-enrichment sampling date (Day 9). All other species except for a few (0 to 4 per core) spionids had disappeared from the enrichment plots on Days 9, 16 and 24 (Fig. 3C). By Day 44, only 5 Capitella sp. remained (in 3 cores). The worms that replaced them were common in the control cores and, because of their large size, probably migrated into the plots as adults. In all enrichment experiments in which particulate material was worked into the sediments, except for the low dose kelp mud enrichment in Expt 2, the sediments darkened and smelled of hydrogen sulfide, suggesting hypoxic and anoxic conditions.

Organic carbon and nitrogen in the sediments at the study site were very low; the percentage of organic carbon in control samples was $0.12 \%$ (SD 0.013) and nitrogen was $0.02 \%$ (SD 0.005). The carbon to nitrogen ratio (6.37) was surprisingly low, falling within the expected range for phytoplankton (Parsons et al. 1984). After $18 \mathrm{~d}$, the low dose kelp mud enrichment did not differ from controls. However, the other enriched plots contained 6 to 8 times the organic content of controls. Except for the milorganite enrichment (C/N of 3.5), the $\mathrm{C} / \mathrm{N}$ ratios within the enrichments were similar to controls. Organic carbon levels were only slightly elevated $36 \mathrm{~d}$ after enrichment, and nitrogen content was not different from controls ( $\mathrm{C} / \mathrm{N}$ was thus elevated with respect to controls).

The density of Nebalia daytoni was not consistently affected by the presence of carrion (dead fish) 1 or $3 \mathrm{~d}$ following deployment of the bait (Fig 4, Table 4), although the fish flesh was approximately 75 to $90 \%$ consumed by Day 3. Other taxa were not evaluated. On 2 occasions ray carcasses were found in the vicinity of the study site. One of those was in a late stage of decomposition, with darkened sediment underlying and surrounding the carcass suggesting that it had
Table 3. Milorganite enrichment. Summary of repeated measures ANOVA results. Treatments are control, disturbance control, and milorganite enrichment

\begin{tabular}{lrrrc|}
\hline Source of variation & df & MS & $F$ & p \\
\hline Nebalia daytoni: & & & & \\
$\quad$ Treatment & 2 & 11.35 & 1.60 & 0.2902 \\
$\quad$ Error & 5 & 7.09 & & \\
Amphipods: & & & & \\
$\quad$ Treatment & 2 & $2.15 \times 10^{3}$ & 36.04 & $<0.0011$ \\
$\quad$ Error & 5 & $5.97 \times 10^{1}$ & & \\
Polychaetes: & & & & \\
$\quad$ Treatment & 2 & $3.00 \times 10^{5}$ & 51.00 & 0.0005 \\
$\quad$ Error & 5 & $5.87 \times 10^{3}$ & & \\
\hline
\end{tabular}

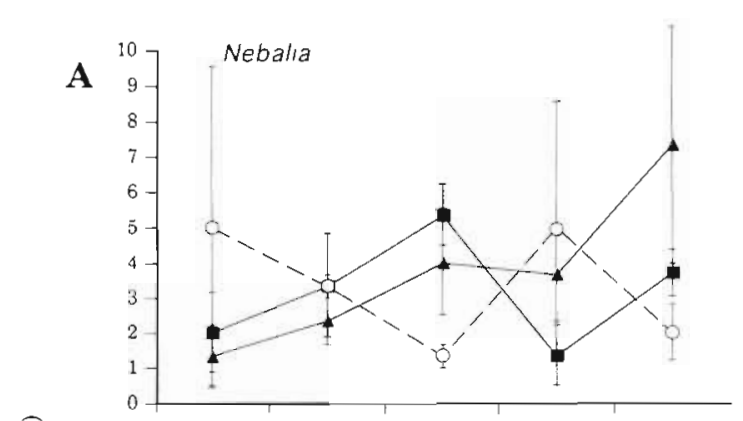

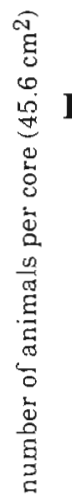
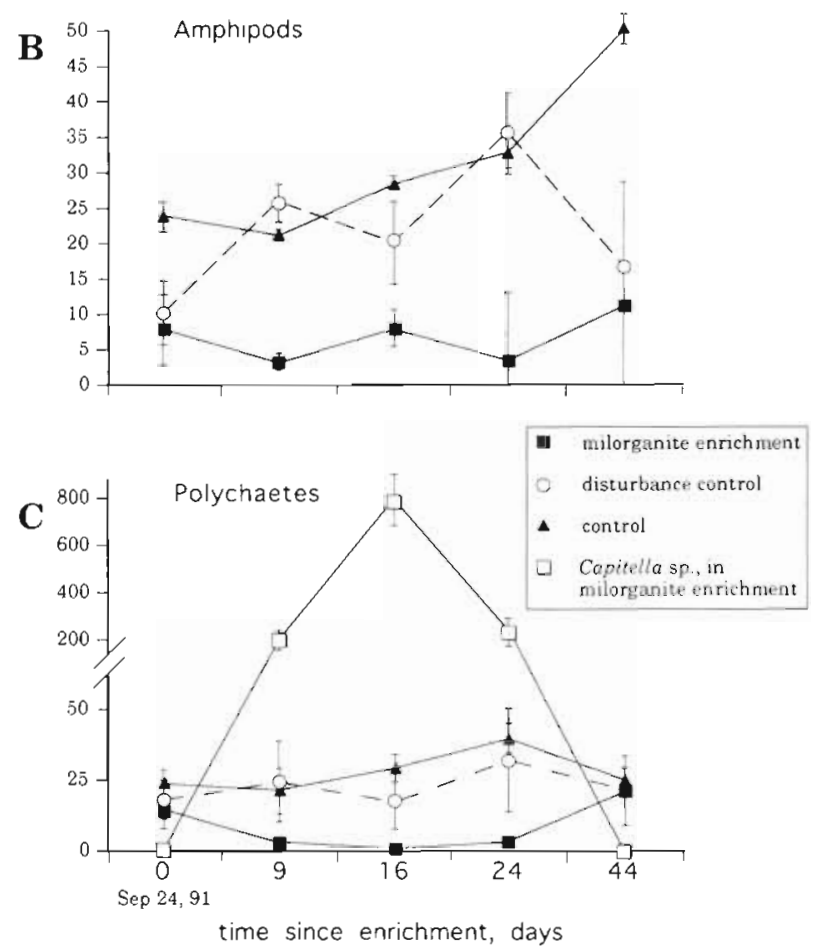

Fig. 3. Milorganite enrichment. Numbers of Nebalia daytoni, umphipods, and polychaetes in unnldnipuided piors and within plots enriched with fertilizer and plots manipulated to simulate the disturbance caused by mixing fertilizer into the sand. Note the change in scale in (C). Error bars are $1 \mathrm{SD}$ 


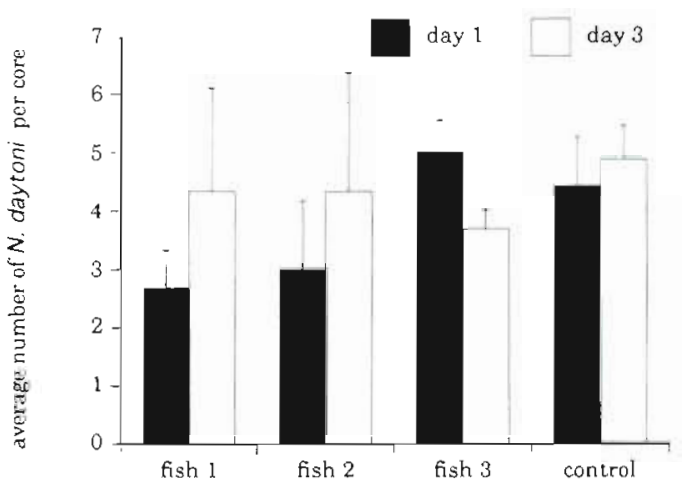

Fig. 4. Nebalia daytoni. Density adjacent to each of 3 parcels of carnon (kelp bass), 1 and $3 \mathrm{~d}$ after deployment. Error bars are $1 \mathrm{SE}$

Table 4. Nebalia daytoni. Response to bait 1 and 3 d following placement of carrion. Summary of nested ANOVA results with treatment type |near carrion or away from carrion i= control)\} as the independent variable and density of $N$. daytoni (per core) as the dependent variable. Treatment type was nested in Plot. There were 6 plots, 3 with each treatment type. Three cores were taken in each plot

\begin{tabular}{|lrccc|}
\hline Source of variation & df & MS & $F$ & $\mathrm{p}$ \\
\hline Day 1: & & & & \\
Nebalia daytoni: & & & & \\
$\quad$ Treatment & 1 & 3.56 & 0.74 & 0.408 \\
$\quad$ Plot (Treatment\} & 4 & 3.11 & 0.64 & 0.642 \\
$\quad$ Residual & 12 & 4.83 & & \\
& & & & \\
Day 3: & & & & \\
N. daytoni: & 1 & 2.72 & 0.49 & 0.499 \\
$\quad$ Treatment & 4 & 0.611 & 0.11 & 0.977 \\
$\quad$ Plot Treatment\} & 12 & 5.611 & & \\
$\quad$ Residual & & & & \\
\hline
\end{tabular}

probably been lying in the same place for at least several days. Several Capitella sp. were present in a nonquantitative sediment sample taken near that carcass.

\section{Field collections and annual cycles of abundance}

Average sediment grain sizes at 18 and $21 \mathrm{~m}$ in March 1995 were 3.03 and 2.97 , respectively. In all 7 cores taken for quantifying of vertical distribution (all on different dates), the Nebalia daytoni was found only in the top $5 \mathrm{~cm}$ of the sand (Fig. 5). Most of the polychaetes were in the top $10 \mathrm{~cm}$, but some were present as deep as 31 to $35 \mathrm{~cm}$. Amphipods were most abundant from the surface to $10 \mathrm{~cm}$ into the sediment, though a few were found deeper. All other taxa (clams, nemerteans, cumaceans, ostracods, platyhelminthes, gastropods, ophiuroids) were only present in the upper $5 \mathrm{~cm}$.

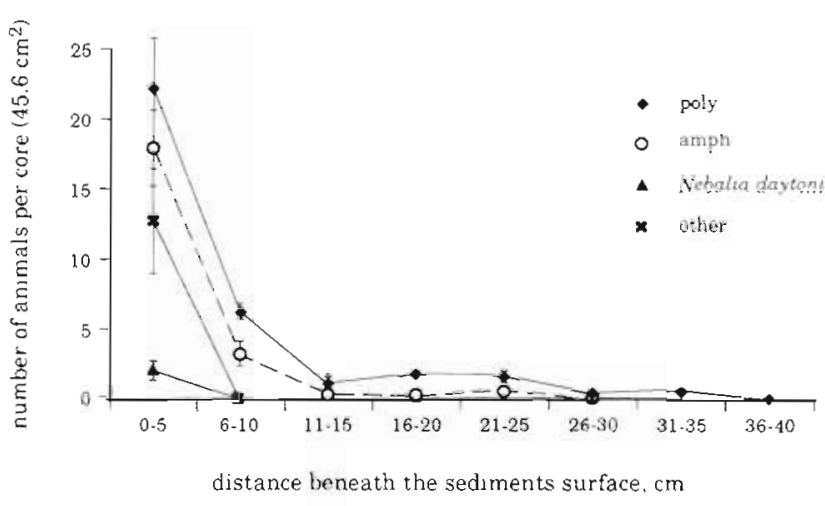

Fig. 5. Depth distribution of polychaetes, amphipods, Nebalia daytoni, and all other taxa within the sand near the depth of maximum abundance of $N$. daytoni $(20 \mathrm{~m})$. Error bars are $1 \mathrm{SD}$

Nebalia daytoni and the amphipod assemblage as a whole both underwent distinct annual cycles of abundance, although they were out of phase with one another. From June 1991 to June 1993, the density of $N$. daytoni averaged 950 ind. $\mathrm{m}^{-2}$ (SD 300), with maximum abundance in late spring-early summer, and minimum in late summer-early fall (Fig. 6A). Amphipod density also had a seasonal pattern, but with peak abundance in late fall and early winter, and low values in spring and summer (Fig. 6B). Average amphipod density was 4800 ind. $\mathrm{m}^{-2}$ (SD 2300). The annual pattern of amphipod abundance (Fig. 6B) dominated that of all other infauna. Average polychaete density was 4200 ind $\mathrm{m}^{-2}$ (SD 1060), with lowest abundance in spring (Fig. 6C). All other taxa were grouped together. The only pattern among the 'other' taxa was a sharp increase from September to December 1991, followed by a rapid decline (Fig. 7A). No single taxon dominated this increase; bivalves, ostracods, nemerteans, ophiuroids and gastropods all figured prominently. The average density of all infauna over the period of study was about 15000 ind. $\mathrm{m}^{-2}$ (Fig. 7B); approximately the same density was found by VanBlaricom (1978) 15 yr earlier.

There was a large decrease in non-polychaete macrofaunal abundance following June 1992. In the furst 12 mo of the record, the density of all non-polychaete macrofauna averaged 13800 ind. $\mathrm{m}^{-2}$; in the subsequent $12 \mathrm{mo}$ they averaged $10500 \mathrm{ind} \mathrm{m}^{-2}$ (ANOVA: $p=0.019$ ). This decrease was driven largely by lower numbers of amphipods and leptostracans rather than the 'other' category.

\section{DISCUSSION}

Studies of naturally or anthropogenically enriched sedimentary habitats have consistently demonstrated 

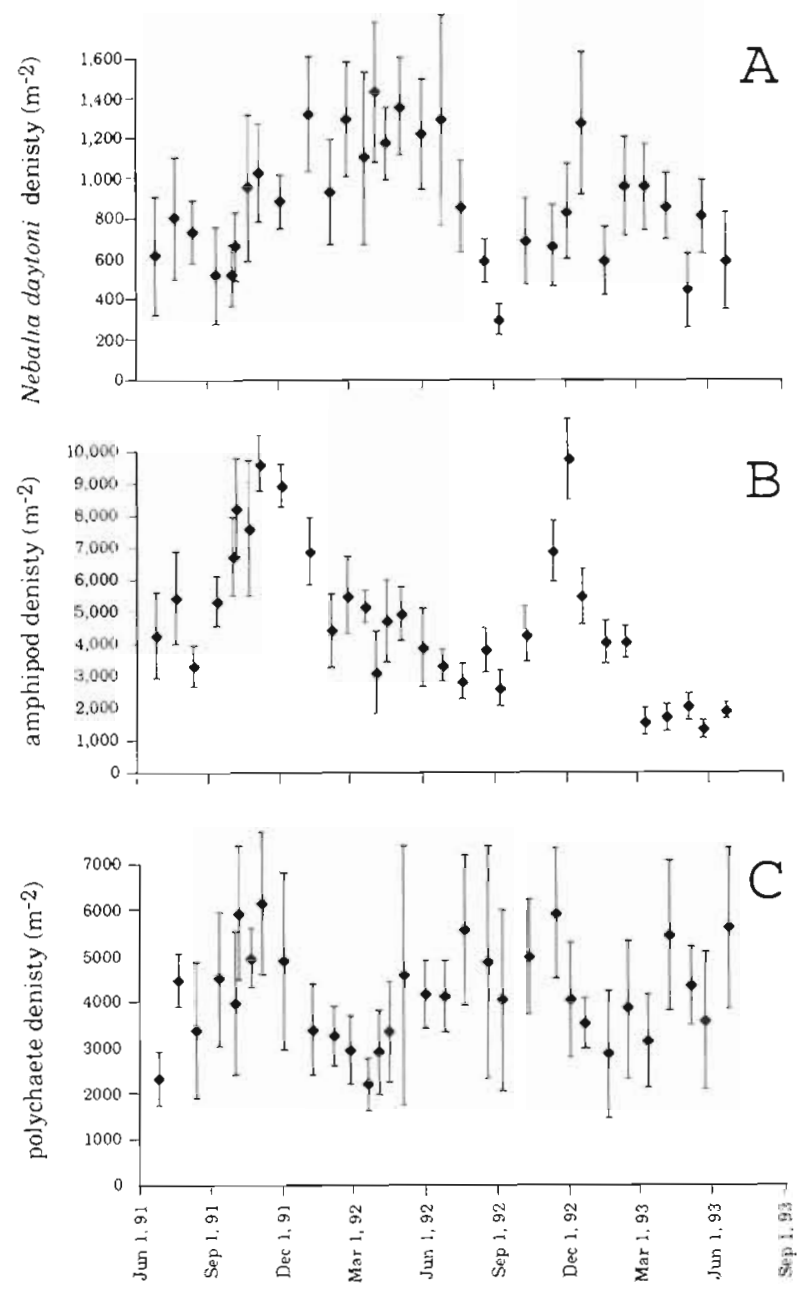

Fig. 6. Density (no. $\mathrm{m}^{-2}$ ) of (A) Nebalia daytoni, (B) amphipods, and (C) polychaetes at $20 \mathrm{~m} . \mathrm{N} \geq 9$ cores; error bars are $1 \mathrm{SD}$

negative effects on the fauna normally present in undisturbed conditions. The trajectory of the community response to enrichment generally involves a continual decrease in diversity, and replacement of the pre-disturbance community with a depauperate disturbance assemblage dominated by a few opportunists (Pearson \& Rosenberg 1978, Conlan \& Ellis 1979, Thrush 1986, Gray 1989, Weston 1990). The effects in the present study essentially conformed to that pattern, and did not vary with the enriching material, but, predictably, depended on the level of enrichment. The initial prediction that this community was in some measure adapted to periodic enrichments was based upon the presence of large numbers of leptostracan crustaceans (Nebalia daytoni). Most of the literature on the genus Nebalia is taxonomic, and the few papers thia i dedi with naturai history tocus on species that inhabit intertidal mud-flats rich in organic matter (Menzies \& Mohr 1952, Ricketts et al. 1985), vegetated or detritus habitats (Kazmi \& Tirmizi 1989, Rainer \& Unsworth 1991, Vetter 1994), or polluted waters (Citarella 1965); an additional study concerns Nebalia sp. scavenging on carrion (Nishimura \& Hamabe 1964). Snelgrove (1993) found that a continental slope (depth $900 \mathrm{~m}$ ) species of Nebalia, presumably living in generally non-enriched conditions such as those in this study, achieved very high densities in experimental trays enriched with either Sargassum sp. or Thalassiosira sp. Judging by the habitats and behavior of its morphologically very similar congeners, it seemed reasonable to expect $N$. daytoni to respond favorably to enrichment.

In all enrichment experiments (except the low dose kelp mud treatment), the pre-disturbance polychaete assemblage was replaced by a virtual monoculture of Capitella sp., a species not present prior to the enrichments. This population explosion no doubt resulted from settlement of larvae that were probably produced by large populations of the capitellids in sediments naturally enriched with kelp and surfgrass detritus about $600 \mathrm{~m}$ from the study site (Vetter 1995). VanBlaricom (1982) also noted that just inshore of the present study site (at $17 \mathrm{~m}$ ), Capitella was absent in the sediment, but recruited heavily to jars of azoic sand. In an enrichment experiment conducted in the Santa Barbara Channel (Southern California, USA) at $16 \mathrm{~m}$, Spies et al. (1988) used an array of containers $(8.1 \times 8.1$ $\times 6 \mathrm{~cm})$ filled with azoic sand enriched with various amounts of kelp Macrocystis pyrifera or oil. As in the
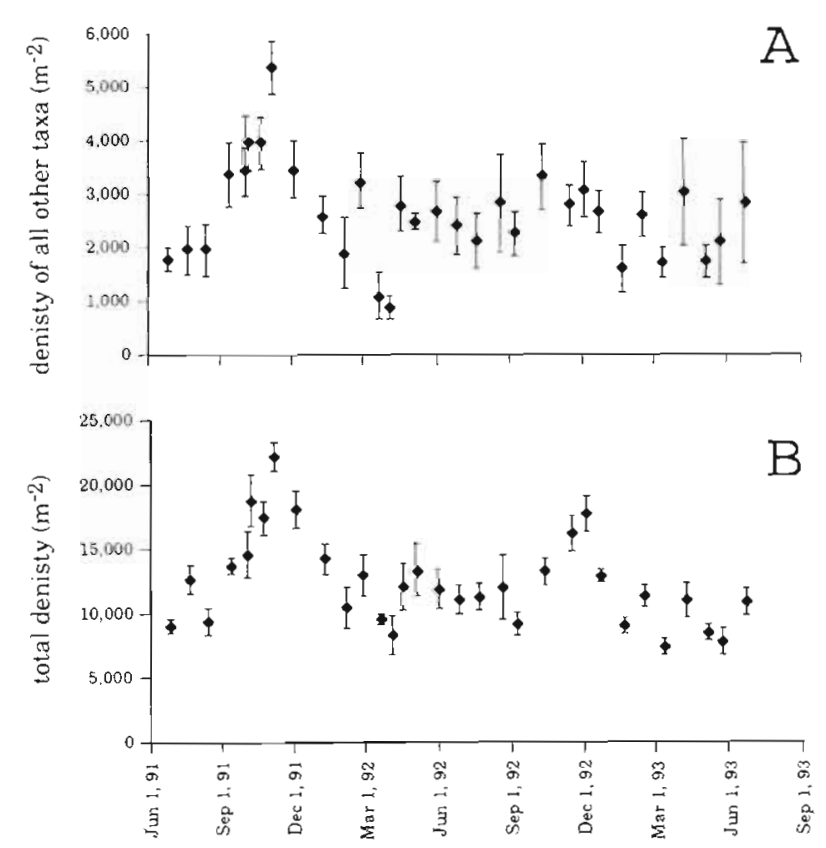

Fig. 7 Density (no. $\mathrm{m}^{-2}$ ) at $20 \mathrm{~m}$ of (A) all invertebrates other than Nebalia daytoni, amphipods and polychaetes; and (B) all macrofaunal invertebrates. $N \geq 9$ cores; error bars are $1 \mathrm{SD}$ 
present study, few species other than a single species of Capitella with planktotrophic larvae recruited into heavily enriched containers.

Even if larvae were immediately available for recruitment, it is remarkable that the recruits managed to mature and produce eggs within $9 \mathrm{~d}$ in plots enriched with fertilizer. The density of Capitella $s p$. was high on Day 10 of corral Expt 2 in one of the alginate enrichment plots, but no eggs were present. Eggs were found in both alginate plots by Day 17 of that experiment. In controlled laboratory experiments, Bridges et al. (1994) found that Capitella sp.1 raised in sediments supplemented with milorganite ${ }^{\circledR}$ or bluegreen algae grew faster, attained a dramatically larger size, and reproduced sooner than animals raised in untreated marsh mud. In addition to greatly increasing the organic content of the sediment, those enrichments substantially lowered their $\mathrm{C} / \mathrm{N}$ ratios, thus increasing both the quantaty and quality of availdule food (TEnore 1975, 1983). The kelp mud and alginate enrichments did not affect the $\mathrm{C} / \mathrm{N}$ ratio of the sediments, but the sediments here have a normally low $\mathrm{C} / \mathrm{N}$ ratio, and aigail detritus is generally readily utilizable by Capitella spp. (Tenore 1983). The milorganite enrichments did depress sediment $\mathrm{C} / \mathrm{N}$ ratios relative to controls, and Capitella sp. within those enrichments matured earlier than those in alginate enrichments, suggesting that the lower nitrogen levels in the alginate were less favorable for capitellid growth.

The Capitella sp. recruited to the enriched plots in the first 2 to $3 \mathrm{wk}$ after enrichment when the production of hydrogen sulfide, a probable larval settlement cue for these polychaetes (Cuomo 1985), would have presumably been strongest. Capitella $\mathrm{sp}$. have a life history as short as $30 \mathrm{~d}$ (Reish 1977), so within about a month of the cessation of the production of the sulfide settlement cue (assuming that this was the sole cue available during this study, and that its loss and food loss were concurrent), it would be reasonable to expect the population to begin to recede, as was observed. Rapid decreases of populations of opportunistic species have been frequently witnessed (McCall 1977), and may often be due to a density dependent depletion of food (Grassle \& Grassle 1974), although predation may also be an important factor in some population declines (Young \& Young 1978). Further, in areas where enrichment is especially great, development of very strong reducing conditions also leads to rapid population reductions (Tsutsumi 1990).

Naturally enriched areas are important for the growth and reproduction of opportunistic species (Tsutsumi et al. 1990) but, away from mud flats and other enriched coastal habitats, natural enrichments are probably ephemeral and patchy. Vertebrate carcasses such as the rays observed during this study could be an important source of such patchiness Smith $(1985,1987)$ concluded that vertebrate carcasses were an important source of food to the deep sea floor $(1310 \mathrm{~m})$ within the Southern California Bight; however, he reported that little of the meat was available to the infauna without first passing through the guts of motile scavengers. Many large scavengers are present in the location studied here (especially crabs and asteroids); it may be that carcasses persisting long enough to enrich the sediments are the exception rather than the rule. The most common patches of elevated food found in this study site are detrital accumulations within pits formed by foraging rays. Flocculant organic matter, and pieces of macroalgae and surfgrass, are common in these pits, which have elevated organic carbon, nitrogen and nitrogen-to-carbon ratios relative to undisturbed areas (VanBlaricom 1978). The disturbance that results from the creation of these patches, and tho subsequent organic enrichment, did not. however, result in recruitment of Capitella sp. (VanBlaricom 1978, author's pers. obs.).

Amphipods are highly sensitive to organic enrichment and other environmental disturbances (Thomas 1993 and references therein), so it is not surprising that there were few or no amphipods in enrichment plots; however Acuminodeutopus heteruropus and Synchelidium shoemakeri were considered to be likely candidates to respond positively to the enriched plots because of their affinity for the detritus rich conditions in newly formed ray pits (VanBlaricom 1982). Contrary to expectation, Nebalia daytoni did not increase in abundance in enrichment plots. Its abundance was lower in the first corral experiment. However, that appeared to be due to cage effects rather than the enrichment (Fig 1). In both subsequent experiments, there was no significant difference in $N$. daytoni density between enrichment and control plots. This, along with the observation that the leptostracans did not respond to carrion, demonstrates that not all members of this genus are trophically similar.

Another Nebalia sp. in Southern California was found to have a refuge from predation in nearby mats of kelp and surfgrass detritus (Vetter 1995). The fake surfgrass treatments were designed to give similar protection from predation by fishes without altering food supply. Rather than increasing in abundance in these plots, $N$. daytoni abundance was lower (Day 48) or similar to (Day 95) controls. None of the habitat manipulations led to an increase in $N$. daytoni, and when their abundance was reduced, a cage effect was indicated.

The seasonal cycle in abundance is less dramatic for Nebalia daytoni than for the amphipods, possibly due to a longer hatching period in the leptostracans. $N$. daytoni is an annual, semelparous species, with maxi- 
mal abundance of adults during summer and few if any present during winter months (Vetter 1996). The strong seasonal cycle of abundance of amphipods suggests that they also largely complete their life cycles within a year, with high adult mortality following release of the young from the marsupium in autumn. Alternatively, the rapid decline in amphipod density during winter could be due to high juvenile mortality. Support for the assertion that the amphipod assemblage is dominated by annuals is found in latitudinal trends in amphipod life histories. Morino (1978), Highsmith \& Coyle (1991), and Sainte-Marie (1991) reported that temperate amphipods generally have annual life histories, in contrast to 2 to 5 yr cycles in higher latitude amphipods and 4 to 6 mo cycles in lower latitude ones. Further, according to Wildish (1982), amphipods with annual life histories may be either semelparous or iteroparous (with some variation between populations within a species); so the rapid rise in amphipod abundance from September to December (Fig. 6B) is likely due to most of the amphipods releasing their broods at that time, and the subsequent decline in abundance may be attributed to senescence in annual species. Annual cycles of abundance of several amphipod species were also observed by VanBlaricom (1978), though periods of maximum abundance tended to occur slightly earlier in the year.

All taxa, with the exception of polychaetes, were more abundant from June 1991 to June 1992 than in the subsequent 12 mo period. Density reduction began 4 to 5 mo following the onset of El Niño conditions within the California Current. Environmental changes at this study site included positive sea surface temperature anomalies and a thicker mixed layer (Hayward 1993, Hayward et al. 1994). It is intriguing to speculate that such environmental change may have directly affected faunal abundances in this study, although no other data exist to test this idea.

Experimental studies by VanBlaricom $(1978,1982)$ demonstrated that community dynamics in this habitat were largely driven by localized disturbances resulting from ray foraging. Pits created by rays accumulated organic debris which was attractive to some infaunal species and repellent to at least one, the amphipod Rhepoxynius abronius. From 1974 to 1977, VanBlaricom found that on average about $25 \%$ of the bottom was in some stage of recovery from disturbance, and during peak foraging periods of the rays, that value approached $100 \%$. That pattern has since changed. with ray disturbance being much less frequent. During the period of this study, it was unusual to find more than $5 \%$ of the bottom recovering from ray disturbance (ainhor's jeis. uis.), ana rays were intrequently seen. Other changes since the mid 1970 s include increased average grain size of the sediment from about 3.26 to
$3.03 \phi$ at $18 \mathrm{~m}$ and from about 3.20 to $2.97 \phi$ at $21 \mathrm{~m}$ (1970s data from VanBlaricom 1978) and shifts in the depth distribution of some infaunal invertebrates. For example, the seaward edge of the zone dominated by crustaceans shifted from $18 \mathrm{~m}$ to beyond $22 \mathrm{~m}$, and the depth of maximum abundance for Nebalia daytoni shifted from about $18 \mathrm{~m}$ to $21 \mathrm{~m}$. Density of $N$. daytoni has also increased from 400 ind. $\mathrm{m}^{-2}$ in 1977 to over 900 ind $\mathrm{m}^{-2}$ in 1993. The increased grain size of the sediment, decreased density of ray pits, faunal shift seaward, and changes in the abundance of some taxa represent an interdecadal change in biological and physical parameters at this site.

The present study highlights the hazards involved with generalizing life history traits across taxonomic levels as low as the genus. The failure of Nebalia daytoni to respond to organic enrichment demonstrates a tolerance to eutrophic conditions, but unlike their congeners thus far studied, there was apparently no exploitation of the increased availability of resources under such conditions. The inability of any members of the native community to take advantage of the pulsed enrichments suggests that such events are not common on the sand flat studied. The rapid exploitation of the artificial enrichments by Capitella sp. was likely facilitated by a nearby source of larvae from populations living in the naturally enriched conditions of the La Jolla Submarine Canyon, California (Vetter 1995). Had the present study been conducted in a region more distant from a natural Capitella habitat, different macrofauna, or perhaps primarily meiofauna and/or microbes would have been the chief beneficiaries of the enrichments.

Acknowledgments. l am grateful to P. K. Dayton, J. T. Enright, R. R. Hessler, N. D. Holland, L. A. Levin and 3 anonymous reviewers for their critical comments on various versions of this manuscript. For help with the design and fabrication of underwater equipment I thank R. R. McConnaughey. I am especially grateful to divers P. L. Brueggeman, M. D. Stokes, R. J. Van Syoc and many others who made this work possible Thanks also to C. Barillotı of KELCO for providing kelp mud and alginate for enrichment experiments. This research was supported in part the by L. A. Chapter of the Achievement Rewards for College Scientists Foundation and the Scripps Institution of Oceanography Diving Locker This paper is part of a dissertation submitted for a PhD in Oceanography at Scripps Institution of Oceanography, UCSD.

\section{LITERATURE CITED}

Ansari ZA, Ingole BS, Parulekar AH. (1986) Effect of high organic enrichment of benthic polychaete population in an estuary. Mar Pollut Bull 17:361-365

Bennett BA, Smith CR, Glaser B, Maybaum HL (1994) Faunal community structure of a chemoautotrophic assemblage uil wirale bones in the deep northeast Pacific Ocean. Mar Ecol Prog Ser 108:205-223

Bridges TS, Levin LA, Cabrera D, Plaia G (1994) Effects of sediment amended with sewage, algae, or hydrocarbons 
on growth and reproduction in two opportunistic polychaetes. J Exp Mar Biol Ecol 177:99-11.9

Brusca RC, Brusca GJ (1990) Invertebrates. Sinauer, Sunderland, MA

Citarella G (1965) Sur une espèce indicatrice de pollution des eaux marines. Rev Trav Inst Peches Marit 29(2): $179-182$

Conlan KE. Ellis DV (1979) Effects of wood waste on sand-bed benthos. Mar Poll Bull 10:262-267

Cuomo MC (1985) Sulphide as a larval settlement cue for Capitella sp. 1. Biogeochemistry 1:169-181

Dauer DM. Conner WG (1980) Effects of moderate sewage input on benthic polychaete populations. Estuar Mar Sci $10: 335-346$

Dayton PK, Hessler RR (1972) Role of biological disturbance in mantaining diversity in the deep sea. Deep Sea Res 19 : $199-208$

Grassle JF, Grassle JP (1.974) Opportunistic life histories and genetic systems in marine benthic polychaetes. J Mar Res 32:253-284

Grassle JF, Grassle JP (1994) Notes from the abyss: the effects of a patchy supply of organic material and larvae on softsediment benthic communities. In Giller PS, Hij.drew AG. Raffaelli DG (eds) Aquatic ecology: scale, pattern and process. Blackwell Scientific, London, p 499-515

Grassle JP, Grassle JF (1976) Sibling species in the marine pollution indicator Capitella. Science, 192:567-569

Gray JS (1989) Effects of environmentai stress on species rich assemblages. Biol J Linnean Soc 37:19-32

Hay ME, Fenical W (1988) Marine plant-herbivore interactions: the ecology of chemical defense. A Rev Ecol Syst 19 $111-145$

Hayward TL (1993) Preliminary observations of the 1991-1992 El Niño in the California Current. CaICOFI Rep 34:21-29

Hayward TL, Mantyla AW, Lynn RJ, Smith PE, Chereskin TK (1994) The state of the California Current in 1993-1994. CalCOFI Rep 35:19-35

Highsmith RC, Coyle KO (1991) Amphipod life histories: community structure, impact of temperature on decoupled growth and maturation rates, productivity and $\mathrm{P}: \mathrm{B}$ ratios. Am Zool 31:861-873

Kazmi QB, Tirmizi NM (1989) A new species of Nebalia from Pakistan (Leptostraca). Crustaceana 56:293-298

Levin LA (1986) Effects of enrichment on reproduction in the opportunistic polychaete Streblospio benedicti (Webster): a mesocosm study. Biol Bull 171:143-160

Levin LA, Plaia GR, Huggett CL (1994) The influence of natural organic enhancement on life histories and community structure of bathyal polychaetes. In: Young $\mathrm{CM}$, Eckelbarger KJ (eds) Reproduction larval biology, and recruitment of the deep-sea benthos. Columbia University Press, New York, p 261-283

Levin LA, Thomas CL (1989) The influence of hydrodynamic regime on infuanal assemblages inhabiting carbonate sediments on central Pacific seamounts. Deep Sea Res 36: $1897-1915$

McCall PL (1977) Community patterns and adaptive strategies of the infaunal benthos of Long Island Sound. J Mar Res 35:221-226

Menzjes RJ, Mohr JL (1952) The occurrence of the wood-boring crustacean Limnona and of Nebaliacea in Morro Bay, California. Wasmann J Biol 10:81-87

Morino H (1978) Studies on the Talitridae (Amphipoda, Crustacea) in Japan. III. Life history and breeding activities of Orchestia platensis Krøyer. Publ Seto Mar Biol Lab 24: $245-267$
Nishimura S, Hamabe M (1964) A case of economical damage done by Nebalia. Publ Seto Mar Biol Lab 12:57-59

Parsons TR, Takahashi M, Hargrove B (1984) Biological oceanographic processes. Pergamon Press, New York

Pearson M. Pearson TH (1991) Variation in populations of Capitella capitata (Fabricius, 1780) (Polychaeta) from the west coast of Scotland. Ophelia Suppl 5:363-370

Pearson TH, Rosenberg R (1978) Macrobenthic succession in relation to organic enrichment and pollution of the marine environment. Oceanogr Mar Biol A. Rev 16:229-311

Priede IG, Bagley PM. Armstrong JD, Smith KL Jr, Merrett NR (1991) Direct measurement of food falls by deep-sea demersal fishes. Nature 351:647-649

Rainer SF, Unsworth P (1991) Ecology and production of Nebalia sp. (Crustacea: Leptostracal in a shallow-water seagrass community. Aust J Mar Freshwat Res 42:53-68

Reish DJ (1977) The role of life history studies in polychaete systematics. In: Reish DJ, Fauchald K (eds) Essays on polychaetous annelids, in memory of Dr Olga Hartman Allan Hancock Foundation Special Publication, Los Angeles, p 461-476

Rice AL, Lambshead PJD (1994) Patch dynamics in the deepsea benthos: the role of a heterogeneous supply of organic matter. In: Giller PS, Hildrew AG, Raffaelli DG (eds) Aquatic ecology: scale, pattern and process. Blackwell Scientific, London, p 469-497

Ricketts EF, Calvin J, Hedgepeth JW. Phillips DW (1985) Betwoen Dacific tides. Stanford Iniversity Press, Stanford, CA

Ritz DA, Lewis ME, Shen M (1989) Response to organic enrichment of infaunal macrobenthic communities under salmonid cages. Mar Biol 103:211-214

Sainte-Marie B (1991) A review of the reproductive bionomics of aquatic gammaridean amphipods: variation of life history traits with latitude, depth, salinity, and superfamily. Hydrobiologia 223:189-227

Sardá R, Foreman K, Valiela I (1992) Controls of benthic invertebrate populations and production of salt marsh tidal creeks: experimental enrichment and short- and long-term effects. In: Colombo G. Ferrari I, Ceccherelli VU, Rossi R (eds) Marine eutrophication and population dynamics. Olsen \& Olsen, Fredensborg, p 85-91

Schram FR (1986) Crustacea. Oxford University Press, New York

Smith CR (1985) Food for the deep sea: utilization, dispersal, and flux of nekton falls at the Santa Catalina Basin floor. Deep Sea Res 32:417-442

Smith CR (1986) Nekton falls, low-intensity disturbance and community structure of infaunal benthos in the deep-sea. J Mar Res 44:567-600

Smith CR (1987) Food energy supply and demand: a discrepancy between particulate organic carbon flux and sediment community oxygen consumption in the deep sea Limnol Oceanogr 32:201-220

Smith CR, Kukert H, Wheatcroft RA, Jumars PA, Deming JW (1989) Vent fauna on whale remains. Nature 341:27-28

Snelgrove PVR (1993) The importance of fine-scale flow processes and food availability in the maintenance of softsediment communities. PhD thesis, Massachusetts Institute of Technology/Woods Hole Oceanographic Institution

Snelgrove PVR, Grassle GF, Petrecca RF (1992) The role of patches in maintaining high deep-sea diversity: field experiments with hydrodynamically unbiased colonization trays. Limnol Oceanogr 37:1543-1550

Snelgrove PVR, Grassle JF, Petrecca RF (1994) Macrofaunal response to artificial. enrichments and depressions in a deep-sea habitat. J Mar Res 52:345-369 
Spies RB, Hardin DD, Toal JP (1988) Organic enrichment or toxicity? A comparison of the effects of kelp and crude oil in sediments on the colonization and growth of benthic infauna. J Exp Mar Biol Ecol 124:261-282

Swartz RC, Cole FA, Schults DW, DeBen WA (1986) Ecological changes in the Southern California Bight near a large sewage outfall: benthic conditions in 1980 and 1983. Mar Ecol Prog Ser 31:1-13

Tarazona J, Salzwedel H, Arntz W (1988) Positive effects of 'El Nino' on macrozoobenthos inhabiting hypoxic areas of the Peruvian upwelling system. Oecologia $76: 184-190$

Tenore KR (1975) Detrital utilization by the polychaete, Capitella capitata. J Mar Res 33:261-274

Tenore KR (1983) Organic nitrogen and caloric content of detritus. III. Effect on growth of a deposit-feeding polychaete, Capitella capitata. Estuar Coast Shelf Sci 17:733-742

Thiel H (1978) Benthos in upwelling regions. In: Tomczak M, Boje R (eds) Upwelling ecosytems. Springer-Verlag, New York, p 124-138

Thomas JD (1993) Biological monitoring and tropical biodiversity in marine environments: a critique with recommendations, and comments on the use of amphipods as bioindicators. J Nat Hist 27:795-806

Thrush SF (1986) The sublittoral macrobenthic community structure of an Irish sea-lough: effect of decomposing accumulations of seaweed. J Exp Mar Biol Ecol 96: $199-212$

Tsutsumi H (1990) Population persistence of Capitella sp. (Polychaeta; Capitellidae) on a mud flat subject to environmental disturbance by organic enrichment. Mar Ecol Prog Ser 63:147-156

Tsutsumi H, Fukunaga S, Fujita N, Sumida M (1990) Relationship between growth of Capitella sp and organic enrichment of the sediment. Mar Ecol Prog Ser 63:157-162

This article was submitted to the editor
VanBlaricom GR (1978) Disturbance, predation and resource allocation in a high-energy sublittoral sand bottom ecosystem: experimental analyses of critical structuring processes for the infaunal community. PhD thesis, University of California, San Diego

VanBlaricom GR (1982) Experimental analyses of structural regulation in a marine sand community exposed to oceanic swell. Ecol Monogi 52:283-305

Vetter EW (1994) Hotspots of benthic production. Nature 372 : 47

Vetter EW (1995) Southern California Nebalia, ecology, production, natural history and systematics of three subtidal species. PhD thesis, University of California, San Diego

Vetter EW (1996) Life history patterns of two Southern California Nebalia (Crustacea: Leptostraca): the failure of form to predict function. Mar Biol (in press)

Wägele JW (1983) Nebalia marerubrisp. nov. aus dem Roten Meer Crustacea: Phyllocarida: Leptostraca. J Nat Hist 17 : $127-138$

Weston DP (1990) Quantitative examination of macrobenthic community changes along an organic enrichment gradient. Mar Ecol Prog Ser 61:233-244

Wildish DJ (1982) Evolutionary ecology of reproduction in gammaridean Amphipoda. Int J Invert Reprod 5:1-19

Young DK, Young MW (1978) Regulation of species densities of seagrass-associated macrobenthos: evidence from field experiments in the Indian River estuary, Florida. J Mar Res 36.569-593

Zmarzly DL, Stebbins TD, Pasko D, Duggan RM, Barwick KL. (1994) Spatial patterns and temporal succession in soft-bottom macroinvertebrate assemblages surrounding an ocean outfall on the southern San Diego shelf: relation to anthropogenic and natural events. Mar Biol 118: 293-307

Manuscript first received: June 20, 1995

Revised version accepted: January 8, 1996 